\title{
Schools, Achievement, and Inequality: A Seasonal Perspective
}

\author{
Karl L. Alexander, Doris R. Entwisle, and Linda S. Olson \\ The Johns Hopkins University
}

\begin{abstract}
Are there socioeconomic differences in the seasonality of children's learning over the school year and summer months? The achievement gap across social lines increases during the primary grades, as much research indicates, but descriptive analyses and HLM within-person growth models for a representative panel of Baltimore school children demonstrate that the increase can be traced mainly to the out-of-school environment (i.e., influences situated in home and community). School-year verbal and quantitative achievement gains are comparable for upper socioeconomic status (SES) and lower SES children, but summer gains, when children are out of school, evidence large disparities. During the summer, upper SES children's skills continue to advance (albeit at a slower rate than during the school year), but lower SES children's gains, on average, are flat. This seasonal pattern of achievement gains implies that schooling plays an important compensatory role, one that is obscured when achievement is compared on an annual basis, as is typical. Policy implications of the seasonality of learning are discussed, including support for preventive measures over the preschool years and for programs, possibly including calendar reforms and summer school, to support disadvantaged children's learning year-round.
\end{abstract}

"Pupils Lose Ground in City Schools: The Longer Children Stay in the System, [the] More They Fall Behind" reads a recent headline from Baltimore's local newspaper (Holmes, 1997). Baltimore is where our research is situated, but the headline could as well be about Chicago, Philadelphia, the District of Columbia, or any of the nation's other large-city, high-poverty school systems. The accompanying article compares citywide reading and math achievement test results from Grades 1 through 5 against national norms, comparisons which, as the headline signals, prove none too flattering. This hardly surprises. When evaluated against national achievement standards, these school systems almost always fare badly: their pupils lag behind in the early grades and fall farther back over time (e.g., Education Week, 1998). Such comparisons identify a problem of immense proportions, but whether the school systems in those communities are failing our neediest children, as the headline seems to imply, is much less certain.

When test results for places like Baltimore are compared against national norms, it hardly can be said that like is being compared with like. Baltimore's public school enrollment in 1999 was $86 \%$ African American (Maryland State Department of Education, 1999a, p.1), two thirds of its students received free or reduced-price meals, indicating low family income relative to family size (Maryland State Department of Education, 1999b), and in more than half the city's elementary schools the low-income enrollment exceeded $80 \%$ (The Sun, 1999)—-hardly the national profile.

Recognizing that "place" is a proxy for economic standing and other dimensions of social advantage or disadvantage puts the headline's comparison of test scores in broader perspective. The out-of-school context necessarily explains the lag in achievement levels of low-income and minority youth over the preschool period. This has been documented recently at the national level in the Early Childhood Longitudinal Study (U.S. Department of Education, 2000) and in the Prospects first grade cohort (e.g., Karweit, Ricciuti, \& Thompson, 1994). Comparisons within the city system show much the same pattern: lower socioeconomic status (SES) children in 
our Baltimore research test well below the level of higher SES children at the start of first grade (e.g., Entwisle, Alexander, \& Olson, 1997). ${ }^{1}$

That the out-of-school social context directs children's academic development before they get to "real school" seems self-evident; yet the same life circumstances that undercut school readiness are ever present in young people's lives. The drag of poverty, family stress, and community decay doesn't suddenly turn off when children reach 6 and the school's influence begins to weigh in. This has implications for the social patterning of achievement differentials among school-age children just as it does among preschoolers: the achievement gap across social lines would be expected to widen over time for reasons having nothing at all to do with the schools. ${ }^{2}$

This expectation holds especially for the foundational curriculum that dominates the primary grades. Not many children will learn differential calculus at home, or analyze classical imagery in 17th-century British literature, but rudimentary reading and number skills are quite another matter. These kinds of skills are rehearsed at homealbeit more so in some kinds of households than others (e.g., Hess \& Holloway, 1984; Scott-Jones, 1984; Slaughter \& Epps, 1987)—and are infused in daily experience outside the household as well-although, again, not in equal measure across social lines (e.g., Entwisle, Alexander, \& Olson, 1994).

Simple time trends like those at issue in the headline quoted above confound effects of home, school, and community. Do schools exacerbate unequal school performance across social lines or do they mitigate such inequality? Schools' contribution to learning from a stratification perspective hangs on the answer, but achievement of clarity requires somehow breaking through the familyhome-school entanglement. Typically, this is done piecemeal through statistical means, as when the influence of specific school resources or experiences (e.g., class size, per pupil expenditures, or curriculum placement) is assessed conditional on family background. This is fine for evaluating specific program effects, but holistic understanding of the role of schooling requires a different approach (e.g., Ceci, 1991).

A seasonal perspective on learning achieves clarity on the matter by exploiting the intermittent nature of schooling. Children are "in" their homes and communities year-round, but are "in" school only part of the time. The long summer breakcurrently under assault as antiquated (e.g., Barrett, 1990; Gewertz, 2000; White, 1999)—constitutes time out from school. For children who do not attend summer school, this partitioning of the calendar approximates a "schooled"-"unschooled" natural experiment. By this logic, differences in the patterning of achievement gains across the "schooled"-"unschooled" divide ought to implicate the experience of schooling.

How, then, does learning differ on a seasonal basis, and what do any such differences imply about the schools' role with respect to achievement differences across social lines? To address these questions, we analyze California Achievement Test (CAT) data from the Beginning School Study (BSS). The BSS, an ongoing panel study, has been monitoring the academic and personal development of a representative random sample of children $(N=790)$ who began first grade in the fall of 1982 in 20 of Baltimore's public schools. The achievement data span 5 years, from fall 1982 (first grade for everyone) through spring 1987. This period predates recent increases in summer remediation programs for children in the primary grades (e.g., Cooper, Charlton, Valentine, \& Muhlenbruck, 2000), and few members of the study group attended summer school during the years at issue. The analysis in that regard is a relatively clean implementation of the "schooled""unschooled" logic that directs attention to seasonal differences in learning. In today's environment, with summer programs proliferating, ${ }^{3}$ it would be much harder to achieve such clarity.

Testing was done in the fall and spring each year, covering 5 school years and 4 summers. This time frame spans all of elementary school for children promoted each year (about $60 \%$ of the total) and is aligned with the time frame of the newspaper article with which we began (Holmes, 1997). Higher scores in the fall of the new school year (relative to scores from the previous spring) reflect summer gains; higher scores toward year's end (relative to scores from the previous fall) reflect school year gains. Figure 1 illustrates the calculations involved. It is a simple matter at the level of operations: for summer gains, subtract spring scores from fall scores across adjacent school years; for school-year gains, subtract fall scores from spring scores within school years.

Two kinds of assessments are reported using this general framework. The first is descriptive. 


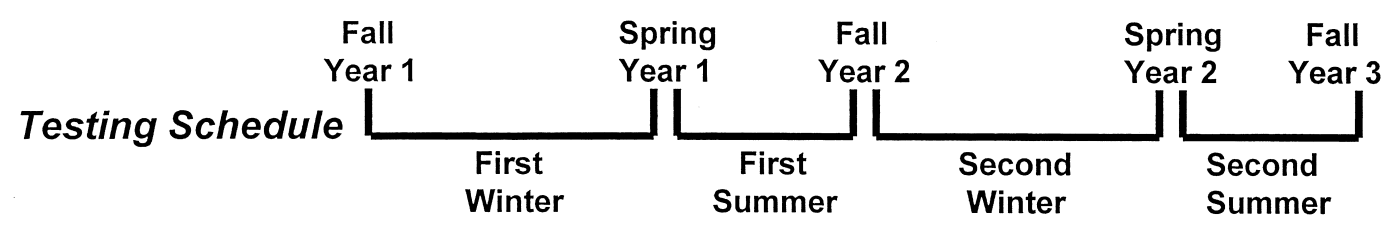

Winter Gains:

First Winter: [Spring Year 1 - Fall Year 1]

Second Winter: [Spring Year 2 - Fall Year 2]

\section{Summer Gains:}

First Summer: [Fall Year 2 - Spring Year 1]
Second Summer: [Fall Year 3 - Spring Year 2]

FIGURE 1. Illustrative timeline for seasonal comparisons of cognitive growth.

It plots achievement levels annually and on a seasonal basis for the 5 school years. These descriptive comparisons highlight how comparisons track across social lines, and especially the insights afforded by taking a seasonal approach in contrast to the more typical approach that monitors performance levels at year's end. The second assessment is analytic. Within-person growth curve trajectories are estimated for the 5 years in a way that allows for summer "deflections" off the annual growth time line and for socioeconomic differences in the magnitude of those deflections. The descriptive comparisons, we will see, seem to implicate out-of-school learning differences as driving the achievement gap across social lines. The growth curve analysis provides a rigorous test of this proposition.

\section{Previous Studies}

Barbara Heyns was among the first to articulate the equity implications of a seasonal perspective on learning, and at the level of issues her empirical work-in the primary grades using national data (1987) and through grades 5 to 7 in Atlanta's public schools (1978) - is the direct-line lineage of BSS inquiries in this area. Interest in the seasonality of learning did not originate with Heyns, however. Cooper, Nye, Charlton, Lindsey, and Greathouse (1996) review 39 relevant studies, the oldest dating back to 1906 (White, 1906). Most of the older studies were interested specifically in summer learning loss, though (as distinct from summer-winter differentials), and few would pass muster against contemporary methodological standards.

Such concerns led Cooper et al. (1996) to restrict their meta-analysis to 13 studies published since 1975. The BSS is one of the 13, represented by two analyses (Entwisle and Alexander, 1992, 1994). Heyns's two studies $(1978,1987)$ are also included. ${ }^{4}$ Cooper et al. conclude that summer losses average about one grade equivalent month across these 13 studies (on the order of .1 standard deviation $[S D]$ relative to spring scores), but this differs across performance domains (math losses exceed reading losses), grade level (losses are larger at the upper grades), and as a function of pupil background (e.g., middle-class children register reading gains over summer; lower-class children register losses).

Here we are particularly interested in the seasonal patterning of achievement gains (and losses) across social lines, and the Cooper et al. (1996, pp. 227-268) review rightly finds broad similarity to Heyns's results and those of the BSS: "The [BSS] analyses largely paralleled that of Heyns (1978). . . . For math concepts, the authors reported a difference in achievement between Whites and Blacks that increased over time and was largely due to differences in summer change. Summer effects were also strongly related to the economic status of children's families. Lower income children showed greater summer losses." And (p. 262): "The results of the meta-analysis support Heyns's (1978) and Entwistle [sic] and Alexander's $(1992,1994)$ contention that socio- 
economic inequities are heightened by the summer break."

In point of fact, the BSS conclusion is that practically the entire gap increase across socioeconomic lines traces to summer learning differentials, and Heyns (1987, p.1154) finds similar results for the Black-White learning gap nationally and much the same in Atlanta (1978) for achievement disparities involving both family income and race/ethnicity. These studies find little (or no) school-year differentiation of achievement gains by race or family SES level and sizable summer differentiation. ${ }^{5}$ Schooling, under this accounting, mitigates effects of social disadvantage in that children's sizable school-year achievement gains depend much less on home resources than do gains over the summer months. And it is impressive, we think, that this broad agreement across studies is evident despite many methodological differences, including population coverage (Atlanta, the United States, Baltimore), the achievement tests, domains of performance and metrics used to measure learning (quantitative and verbal in all instances, but otherwise dissimilar), and grade level and time frame coverage (Grades 5 and 6 at baseline in Atlanta for 18 months, 18 months for successive grade cohorts through the elementary school years in the SES project, and 24 months in the BSS, with fall of first grade as baseline).

The two BSS reports (Entwisle and Alexander, 1992, 1994) reviewed by Cooper et al. (1996) examine the first 2 school years and 2 summers of children's schooling, using repeated MANOVA measures to estimate seasonal differences in learning and possible interactions involving school context (i.e., segregation or integration status) and student background (e.g., race/ethnicity, family socioeconomic background). BSS work since (e.g., Alexander \& Entwisle, 1996a, 1996b; Entwisle, Alexander, \& Olson, 1997), largely descriptive, has plotted seasonal differences in learning for 5 years, the same time frame as in the present inquiry. So far as we know, there is no other study of seasonal learning patterns that spans all of elementary school for a representative sample of school beginners (in the case of the BSS, that sample is urban and low income), and for that reason BSS research on the topic has attracted considerable attention (e.g., Krueger, 2000) ${ }^{6}$

In light of all this work, why revisit the issues here? To date, seasonal learning differences in the
BSS have been evaluated analytically for 2 years and descriptively for 5 . The present paper reports descriptive and analytic results for the full 5-year period in parallel, and in so doing addresses certain questions more authoritatively than heretofore. From the longer term descriptive comparisons, for example, it appears that summer differentials are larger the first 2 years than later, but this has not been evaluated analytically. The growth curve analyses reported here embrace all of the elementary years in a comprehensive way, something not done heretofore. Also, these analyses test the primacy of race versus family SES level versus gender as the source explaining summer learning disparities. Our introductory comments have been cast broadly in terms of achievement differentials "across social lines," but whether there is one "line of divide" that dominates the others remains to be determined. We know from earlier BSS studies, for example, that Whites register greater achievement gains over the summer months than do African Americans, and that upper income children in the BSS register greater summer achievement gains than do lower income children. But we have yet to test for race differences in the seasonality of learning net of family socioeconomic level or for socioeconomic differences in the seasonality of learning net of race. The analyses that follow inform all these issues.

\section{Methods}

\section{The BSS Research Design}

Children were selected for participation in the BSS study through a two-stage process. First, 20 schools were chosen randomly from within strata defined by racial mix (6 predominantly African American; 6 predominantly White; 8 integrated) and by socioeconomic status (14 inner city or working class; 6 middle class); then students were randomly sampled using kindergarten rosters from the previous school year, supplemented by first-grade class rosters after school began in the fall. Ninety-seven percent of children and families so selected were successfully recruited into the project.

The Baltimore context is low-income urban, and this is reflected in the study group's "highrisk" makeup (e.g., Kaufman, Bradby, \& Owings, 1992). The Baltimore City Public School (BCPS) enrollment in the early 1980s was about $77 \%$ 
African American; the original BSS sample of 790 first-time (nonrepeater) first graders was 55\% African American, 45\% White (to sustain comparisons by race, Whites were oversampled). Mother's education for the group averaged a little more than 11 years, with almost $40 \%$ consisting of high school dropouts (44\% of Whites and $34 \%$ of African Americans). According to school records, two thirds of BSS families received free or reduced-price school meals (about the same percentage as in the school system at the time), and many first graders were living in single-parent households (44\% overall, including $30 \%$ of Whites and $56 \%$ of African Americans).

The analysis uses achievement data from school records, demographic information (race/ ethnicity and sex) from school records, and data on family socioeconomic standing obtained from parent interviews and school records. These data sources are described next.

\section{Data Sources}

California Achievement Test (CAT) scores. When the BSS commenced in fall 1982, the BCPS system was administering the CAT battery twice annually, fall and spring. Two subtests from the CAT battery are used: Reading Comprehension (CAT-V: 20 items in the fall of first grade), and Math Concepts and Applications (CAT-M: 36 items in the fall of first grade). Several considerations directed us to these particular domains of performance, mainly the importance of the skill areas themselves. Additionally, ceiling constraints were a problem for other components of the CAT battery. In the spring of first grade, for example, $16.6 \%$ of the cohort received the highest score possible on the Math Computation subtest compared with 3.5\% on the Math Concepts and Applications subtest. The corresponding figures for Vocabulary (not used) and Reading Comprehension (used) were $17.3 \%$ and $3.7 \%$, respectively. Also, modules to assess competence in these two areas are included in all versions of the CAT battery from first grade through high school, which means that the same cognitive domains can be monitored throughout. Trends are reported using CAT scale scores. These are vertically calibrated across versions of the CAT battery designed for administration at different grade levels, approximating a single continuum of performance across all points of comparison.
Sociodemographic data . Race (White $=0$; African American $=1)$ and gender $($ male $=0 ;$ female $=1)$ are from school records, supplemented by selfreports. Family SES is measured as a composite, using information on mother's and father's educational levels, a ranking of mother's and father's occupational status (Featherman \& Stevens, 1982), and receipt of reduced-price school meals, indicative of low family income relative to family size. The first four indicators were self-reported by parents; the last is from school records. The composite is constructed as the average of available measures, after conversion to $\mathrm{Z}$ scores. Scale scores are available for 787 of the 790 group, with just under $70 \%$ calculated on 4 or 5 indicators and $5.4 \%$ on a single indicator. Alpha reliability for the 386 youngsters covered by all five items is .86 .

For descriptive comparisons, a three-category version of the SES composite is used. With the cutting points selected, mother's education averages 10.0 years for the lower SES group, 12.0 years for the middle group, and 14.6 years for the upper group; the respective percentages for participation in the meal subsidy program for low-income families are 95.1, 53.4, and 13.1. There are few genuinely wealthy households in the BSS, and it should be understood that the descriptors used, e.g., "lower" and "higher" or "upper" are relative to the sample's makeup. In fact, half the cohort is located in the lower SES category, a reflection of the study group's low socioeconomic standing overall.

\section{Sample Attrition}

Coverage on the background measures is virtually complete. Sex and race/ethnicity are known for everyone, and only three cases lack scores on the scale that ranks family socioeconomic standing. The CAT data, however, come from 10 test administrations over 5 years, and missing data are a concern. Coverage is sparse for the children (25\%) who transferred out of Baltimore's schools during the primary grades, but absences, lost records, and the like also contribute to gaps in the testing record. There are just 368 children (of the original 790) with all 10 scores on the CAT-V and 371 with all 10 scores on the CAT-M. This has obliged us to consider the consequences of sample attrition carefully. The first and third columns of the Appendix show how youngsters with complete testing data compare with the original sample on various measures from first grade. The 
comparisons are reassuring: despite a high degree of sample loss, attrition is not selective along academic lines and only moderately selective along social lines.

Accordingly, all available data are used in the analysis. The only cases screened out are those for whom growth trajectories cannot reasonably be estimated: those with fewer than three overtime data points per achievement domain (three being the minimum number required to estimate a growth trajectory, allowing for curvature) and those lacking "anchoring" baseline scores from the fall of first grade. These restrictions yield a (maximum) case base of 665 for the CAT-V analysis and a base of 678 for the CAT-M analysis. ${ }^{7}$ These "restricted coverage" samples likewise evidence little attrition bias (see Appendix).

\section{Results}

\section{Annual versus Seasonal Achievement Gains}

What, then, does the achievement pattern look like in the BSS when assessed spring-to-spring, the standard approach? Table 1 shows that lower
SES youth already lag behind their upper SES peers in first grade (by about $0.7 S D$ on both CAT subtests), and after 5 years they are farther back still (by more than $0.9 S D$ ). Raw score differences (i.e., number of CAT points) likewise start out large and increase, but these are not adjusted for the increasing dispersion on scores over time and so must be interpreted with care. ${ }^{8}$

Lower SES youngsters in the BSS thus are not keeping up. This is the pattern typically seen when achievement is assessed at year's end-indeed the newspaper article with which we began could well have been written about the experience of our study group. With these results as a frame of reference, how does the picture change when schoolyear and summer achievement gains are calculated separately? This is done in Table $2,{ }^{9}$ and the exercise informs a whole host of issues having to do with schools and achievement.

First, CAT gains posted while children are in school (top half of Table 2) exceed gains over the summer months (lower half of Table 2), with the school-year margin of advantage large whether calculated as raw score gains or gains per month. ${ }^{10}$

TABLE 1

Spring CAT Performance Levels Over Five Years, by Family Socioeconomic Status (Restricted Samples, $\mathrm{N}=665,678$ )

\begin{tabular}{|c|c|c|c|c|c|}
\hline Family SES level & Spring ' 83 & Spring '84 & Spring ' 85 & Spring ' 86 & Spring ' 87 \\
\hline \multicolumn{6}{|l|}{$\begin{array}{l}\text { CAT-V mean } \\
\text { (Reading) }\end{array}$} \\
\hline $\begin{array}{l}\text { Low SES } \\
(N)\end{array}$ & $\begin{array}{r}329.15 \\
(329)\end{array}$ & $\begin{array}{r}375.95 \\
(308)\end{array}$ & $\begin{array}{r}397.92 \\
(282)\end{array}$ & $\begin{array}{r}433.58 \\
(274)\end{array}$ & $\begin{array}{r}461.17 \\
(292)\end{array}$ \\
\hline $\begin{array}{l}\text { Mid SES } \\
(N)\end{array}$ & $\begin{array}{r}348.68 \\
(161)\end{array}$ & $\begin{array}{r}388.43 \\
(144)\end{array}$ & $\begin{array}{r}423.93 \\
(120)\end{array}$ & $\begin{array}{r}467.52 \\
(118)\end{array}$ & $\begin{array}{r}495.51 \\
(129)\end{array}$ \\
\hline High SES & 361.01 & 418.09 & 460.81 & 506.20 & 534.60 \\
\hline$(N)$ & $(150)$ & (137) & (109) & (99) & (93) \\
\hline High-low difference & 31.86 & 42.14 & 62.88 & 72.62 & 73.43 \\
\hline Pooled $S D$ & 45.65 & 48.39 & 57.85 & 69.77 & 73.92 \\
\hline Difference/pooled $S D$ & .70 & .87 & 1.09 & 1.04 & .99 \\
\hline \multicolumn{6}{|l|}{$\begin{array}{l}\text { CAT-M mean } \\
\text { (Math) }\end{array}$} \\
\hline $\begin{array}{l}\text { Low SES } \\
(N)\end{array}$ & $\begin{array}{r}331.27 \\
(339)\end{array}$ & $\begin{array}{r}371.87 \\
(315)\end{array}$ & $\begin{array}{r}397.80 \\
(289)\end{array}$ & $\begin{array}{r}427.63 \\
(281)\end{array}$ & $\begin{array}{r}357.76 \\
(295)\end{array}$ \\
\hline Mid SES & 350.45 & 387.08 & 418.88 & 457.76 & 491.66 \\
\hline$(N)$ & $(162)$ & (146) & $(122)$ & $(122)$ & (134) \\
\hline High SES & 357.39 & 407.30 & 448.09 & 487.02 & 514.62 \\
\hline$(N)$ & (147) & (135) & $(110)$ & (98) & (91) \\
\hline High-low difference & 26.12 & 35.42 & 50.29 & 59.39 & 56.85 \\
\hline Pooled $S D$ & 36.53 & 38.54 & 48.25 & 54.64 & 60.97 \\
\hline Difference/pooled $S D$ & .72 & .92 & 1.04 & 1.09 & .93 \\
\hline
\end{tabular}

CAT, California Achievement Test. 
TABLE 2

CAT Achievement Gains by Season and Socioeconomic Level: Five Winters, Four Summers (Restricted Samples, $\mathrm{N}=665$ [Verbal], 678 [Quantitative])

\begin{tabular}{|c|c|c|c|c|c|c|}
\hline \multirow[b]{2}{*}{ Season } & \multicolumn{3}{|c|}{ CAT-V (Reading) } & \multicolumn{3}{|c|}{ CAT-M (Math) } \\
\hline & Low SES ${ }^{a}$ & Mid SES ${ }^{a}$ & High SES ${ }^{a}$ & Low SES ${ }^{a}$ & Mid SES ${ }^{a}$ & High SES ${ }^{a}$ \\
\hline \multicolumn{7}{|l|}{ Winter gains } \\
\hline $1 \mathrm{st}$ & $55.94(2.64)$ & $69.86(3.55)$ & $60.09(3.37)$ & $48.84(1.64)$ & $53.79(2.11)$ & $43.71(2.46)$ \\
\hline 2nd & $46.00(2.31)$ & $43.19(3.06)$ & $39.82(3.50)$ & $42.35(1.42)$ & $44.06(2.06)$ & $42.92(2.22)$ \\
\hline $3 \mathrm{rd}$ & $30.46(2.17)$ & $34.34(3.48)$ & $34.68(3.76)$ & $35.50(1.56)$ & $35.68(2.27)$ & $35.96(2.39)$ \\
\hline 4 th & 33.57 (2.24) & $41.29(3.15)$ & $28.52(4.26)$ & $32.94(1.50)$ & $32.88(2.49)$ & $34.71(2.76)$ \\
\hline 5 th & $25.28(2.22)$ & $27.86(3.37)$ & $23.58(4.19)$ & $24.35(1.82)$ & $30.90(2.72)$ & $26.35(3.31)$ \\
\hline Total gain & 191.25 & 216.54 & 186.69 & 183.98 & 197.31 & 183.65 \\
\hline $\begin{array}{c}\text { Mean gain/ } \\
\text { month }^{\mathrm{b}}\end{array}$ & 4.78 & 5.41 & 4.67 & 4.60 & 4.93 & 4.59 \\
\hline \multicolumn{7}{|l|}{ Summer gains } \\
\hline $1 \mathrm{st}$ & $-3.67(2.49)$ & $-3.11(3.46)$ & $15.38(3.05)$ & $-4.89(1.59)$ & $-8.22(2.22)$ & $7.18(2.66)$ \\
\hline 2nd & $-1.70(2.26)$ & $4.18(3.60)$ & $9.22(4.00)$ & $-5.18(1.67)$ & $-.50(2.50)$ & $3.14(2.74)$ \\
\hline $3 \mathrm{rd}$ & $2.74(2.21)$ & $3.68(3.82)$ & $14.51(4.33)$ & $-1.25(1.57)$ & $6.15(2.74)$ & $2.28(2.78)$ \\
\hline 4th & $2.89(2.56)$ & $2.34(3.21)$ & $13.38(4.42)$ & $5.50(1.59)$ & $4.31(2.67)$ & $6.30(3.39)$ \\
\hline Total gain & .26 & 7.09 & 52.49 & -5.82 & 1.74 & 18.90 \\
\hline $\begin{array}{c}\text { Mean gain/ } \\
\text { month }^{\mathrm{b}}\end{array}$ & .02 & .44 & 3.28 & -.36 & .11 & 1.18 \\
\hline
\end{tabular}

Note. Standard errors are reported in parentheses.

CAT, California Achievement Test.

a Sample size ranges for seasonal gains: Low SES $N=264-339$; Mid SES $N=113-162$; High SES $N=85-150$.

${ }^{\mathrm{b}}$ Based on 8 months of winter (Oct-May), 4 months of summer (June-Sept).

Children, it is reassuring to see, learn more and learn more efficiently when they are in school. Second, verbal gains over the summer generally exceed quantitative gains, suggesting that, at least in the early grades, quantitative learning is more school-dependent than verbal learning. Cooper et al. (1996) reach a similar conclusion. Third, consistent with the idea that the period of early schooling is foundational (Entwisle \& Alexander, 1989, 1993), school-year gains generally are larger the first two years than later.

These insights alone would be ample reason to examine learning on a seasonal basis; however, our present interest centers on a fourth issue informed by Table 2: how CAT gains differ by season according to children's family background. School-year gains year by year are not very different across SES levels (upper panel). Indeed, in the early years the comparisons sometimes favor lower and middle SES children over upper. The summer pattern is strikingly different though, especially across the SES extremes. In the verbal area, then, lower SES youth essentially tread water, some summers gaining a few points, some summers losing a few, while in the quantitative domain losses predominate and are especially large over the first two summers. This means that lower SES children generally start the new school year about where they had been the previous spring or even behind their spring levels of performance.

Upper SES children's scores, on the other hand, improve over the summer months (lower panel) in both domains, which means that they begin the new school year ahead of where they had been the previous spring. And the summer differences comparing lower and upper SES youth are large. This is easiest to see when the year-by-year differences are summed across years (i.e., the "total gain" entries in the lower panel of Table 2). These totals favor children from upper SES households by sizable margins, with the differences large enough to account for almost the entire CAT gap increase that emerges over the first 5 years of the panel's schooling. Compare the scale score differences from spring of 1983 to spring of 1987 in Table 1 against the cumulative summer differences in Table $2 .{ }^{11}$ At the end of 5 years, the performance of lower SES children lags far behind, but Table 2 clarifies what is at issue. During the 
school year these children keep up, but they begin first grade already behind and during the summer months, when they are not in school, their skills register very little improvement.

These descriptive comparisons thus seem to implicate the long summer break as the source of lower SES children's achievement shortfall during the primary grades. The analyses reported in the next section test whether the summer shortfall suffered by lower SES children relative to upper is statistically reliable.

\section{Modeling the Time Line of Cognitive Growth on a Seasonal Basis}

Analysis plan. Hierarchical linear modeling (HLM) is used to estimate within-person achievement growth models (Bryk, Raudenbush, and Congdon, 1996; Bryk and Raudenbush, 1992).12 Person-specific growth parameters are estimated at the within-person, or Level 1, stage. These results define the time line of CAT gains across the entire sample — essentially the average or typical pattern. The between-person, or Level 2, parameters evaluate variability in the Level 1 parameters in relation to traits that vary across persons. So, for example, do school-year and summer CAT gains differ for lower and higher SES youth? Our major interest centers on family SES, but effects of race/ethnicity and gender are also controlled at Level 2 to guard against confounding.

Two variants of the model are evaluated. Both specifications fit three growth parameters at Level 1: a baseline intercept term; a linear growth term; and a quadratic term to allow for curvature in the growth trajectory (the rate of gain is expected to decline over time, e.g., Schneider, 1980; Stephens, 1956). The two models differ in how adjustments to the school-year pattern of achievement gains are estimated. The first implements a single summer adjustment term to gauge how summer gains differ from winter gains on average. However, because the summer gain differential by family SES level seems to vary across years (see Table 2), the second growth model estimates a separate adjustment term for each summer.

The data requirements for estimating the second specification of summer deflections are severe, however. At Level 1, person-specific growth trajectories are derived. With separate coding for each summer, these models fit seven parameters (intercept, growth, growth squared, and four sum- mer adjustment terms) to a maximum of 10 data points (fall and spring CAT scores over 5 years). This approaches the limit of the information available, and HLM screens out many cases because of strategic gaps in the testing record. Numbers range from 448 to 458 when four separate summer adjustment parameters are estimated versus 646 to 656 when a single, average summer adjustment is estimated. Notwithstanding such technical concerns, attrition bias owing to missing CAT data seems minor (see Appendix), and all models converged.

Maximum likelihood estimates of parameters in the Level 1 and Level 2 equations for the four summer term models are as follows: ${ }^{13}$

\section{Level 1 Model: Within-Person Growth} Trajectories

$$
\begin{aligned}
Y_{t i}= & \beta_{0 i}+\beta_{1 i} S 1_{t i}+\beta_{2 i} S 2_{t i}+\beta_{3 i} S 3_{t i}+\beta_{4 i} S 4_{t i} \\
& +\beta_{5 i} T_{t i}+\beta_{6 i} T_{t i}^{2}+\varepsilon_{t i},
\end{aligned}
$$

where

$Y_{t i}$ is CAT level at time $t$ for student $i$,

$S 1_{t i} S 4_{t i}$ are summer adjustment dummy variables,

$T_{t i}$ is time, coded at 0 for fall 1982 and incremented by unit steps thereafter for each testing occasion (spring and fall),

$T_{t i}^{2}$ is time squared to allow for nonlinearity in the growth trajectory,

$\beta_{0 i}$ is the expected baseline CAT value for child $i$,

$\beta_{1 i} \ldots \beta_{4 i}$ are summer adjustments to the school-year learning rate for student $i$,

$\beta_{5 i}$ and $\beta_{6 i}$ map the learning rate during the school year,

$\varepsilon_{t i}$ is an estimate of person-level disturbance.

Level 2 Model: Between-Person

Background Contingencies ${ }^{14}$

$$
\begin{aligned}
& \beta_{0 i}=\pi_{00}+\pi_{01} \mathrm{SES}_{i}+\pi_{02} \mathrm{RACE}_{i} \\
& +\pi_{03} \mathrm{SEX}_{i}+v_{0 i} \\
& \beta_{1 i} \ldots \beta_{4 i}=\pi_{10} \ldots \pi_{40}+\pi_{11} \ldots \pi_{41} \mathrm{SES}_{i} \\
& +\pi_{12} \ldots \pi_{42} \mathrm{RACE}_{i} \\
& +\pi_{13} \ldots \pi_{43} \mathrm{SEX}_{i}+v_{1 \ldots 4 i}
\end{aligned}
$$




$$
\begin{aligned}
\beta_{5 i}= & \pi_{50}+\pi_{51} \mathrm{SES}_{i}+\pi_{52} \mathrm{RACE}_{i} \\
& +\pi_{53} \mathrm{SEX}_{i}+v_{5 i} \\
\beta_{6 i}= & \pi_{60}+v_{6 i}
\end{aligned}
$$

where

$\beta_{0 i}, \beta_{1 i} \ldots \beta_{4 i}, \beta_{5 i}, \beta_{6 i}$ are person-level parameter estimates from the Level 1 model,

$\pi$ 's are Level 2 parameter estimates (intercept and slopes), and $v_{0 i} \ldots v_{6 i}$ are Level 2 random effects.

Growth models with a single summer adjustment. Table 3 reports estimates for growth curve models that include a single, average, summer-adjustment term. Results for CAT-V are reported on the left side of the table, for CAT-M on the right side. ${ }^{15}$ The first Level 1 equation (column I) fits linear and quadratic growth terms, with time set to 0 at baseline (fall 1982, or fall of first grade) and incrementing one unit per subsequent testing occasion.

Children's CAT averages at the start of first grade are in the vicinity of 300 scale points in both domains. Both baseline means are significantly different from 0 , as are all four growth terms, with coefficient estimates for the quadratic terms negatively signed (-.96 for CAT-V; -.47 for CAT-M). This indicates that the rate of growth slows over time, as expected. These details of the general time line of achievement growth all are unexceptional. However, the specification in column I does not adjust for summer differences, which means that the parameter estimates describe the growth path period by period $(N=10)$ without regard to possible differences by season.

The second column of results evaluates between-person variability in these growth parameters in relation to family SES (here measured using the full scale metric), sex (with girls coded "1") and race/ethnicity (with African Americans coded "1"). Because of the way Level 1 and Level 2 parameter estimates are "linked" in the HLM framework, the Level 1 coefficients in column II are analogous to intercept estimates in OLS regression-they represent the expected value of the dependent variable for the group defined by the intersection of Level 2 predictors at score 0 . In the present instance, that corresponds to White males with average family SES scores-recall that the SES scores are standardized. The intercept estimate of 292.11 in column II of the CAT-V results thus is the expected score of such youngsters at baseline (fall of first grade). The associated Level 2 coefficients are net increments or decrements to that level of test performance at school entry associated with, respectively, contrasting values of SES, race/ethnicity, and sex. For CAT-V, effects of family SES and sex are significant. With SES scaled in $S D$ units, its associated coefficient in Table 3 indicates a 16.25-point CAT-V difference at the start of first grade for children $1 S D$ apart in family SES. The $S D$ of the CAT-V distribution at baseline is 40.8 points, so 16.25 points corresponds to about $.40 S D .{ }^{16}$ The difference, as expected, favors children in upper SES households. The CAT-V results also show girls' scores slightly above boys' at baseline.

The Level 2 SES difference is much the same for CAT-M performance as for CAT-V, except that the CAT-M gender difference is not significant and the race difference is. African American children in this sample start school a little behind their White counterparts in the quantitative domain. The 4.8 point difference, net of SES and sex, corresponds to roughly .15 CAT-M SD, about the same magnitude as the boy-girl difference in the verbal domain.

The SES differences are the largest of these Level 2 effects on baseline performance. The growth terms show what happens from that point forward. Because the trend is nonlinear, the two terms that describe the growth path have to be evaluated jointly. However, because preliminary analyses revealed no Level 2 effects on the deceleration parameters, in Table 3 (and later, in Table 4) only the "main-effect" terms are specified as contingent on Level 2 influences. Under that framework, lower SES youths' rate of gain over the elementary years lags behind upper SES youths' in both domains, African American youths' rate lags behind White youths' in both domains, and, boys' rate lags behind girls', all significant at the .01 level.

In these results, then, lower SES youth fall farther back over time, as seen by plotting averages (Table 1). However, these estimates do not allow for seasonal differences in growth trajectories. Whether there are such differences, and how they affect growth patterns across social lines, is assessed in columns III and IV of Table 3. 


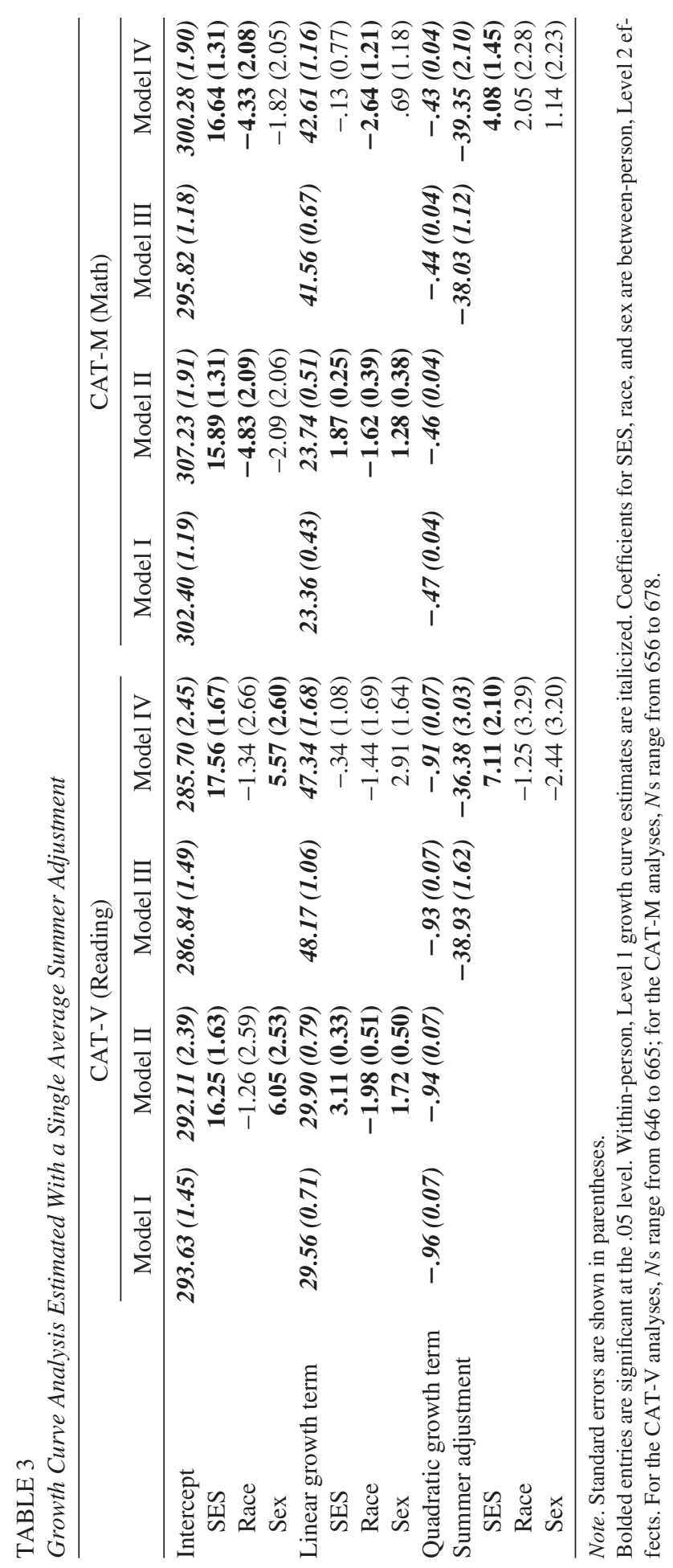


Column III adds a single summer adjustment term to the general time trend to represent an average effect across the four summers subsumed under the model's 5-year time frame. The summer adjustment coefficients for both CAT-V and CAT-M are negatively signed and highly significant, but smaller than the corresponding linear growth coefficients. The descriptive pattern in Table 2 suggested that growth slows during the summer relative to school-year growth, and the results here are consistent with this pattern. However, because the summer coefficients are $a d$ justments to the per period growth that would otherwise be expected over the interval at issue, the summer deflection coefficients in Table 3 do not represent summer drop-off or gain per se. To compare winter and summer gains precisely requires some additional calculations.

"Time," as construed in this analysis, is divided into increments in which one unit corresponds to one season, fall to spring, spring to fall. To see the model's implications in terms of actual summer growth (or loss), we first need to derive the growth implied at time " $t$ " by the general growth specification (i.e., linear and quadratic terms) and then correct that estimate for the summer-winter differential. The first part of the calculation is accomplished by taking the first derivative of the equation implied by column III at time $t$. Evaluating the CAT-V equation at $t=2$, for example, yields an estimate of (instantaneous) growth in the fall of year 2 of 44.45 CAT-V points. Adjusted for the average summer deflection ( -38.93 , from Table 3$)$, the average expected gain for the first summer is 5.52 CAT-V points. ${ }^{17}$ Similar calculations could be done throughout, and in general the model indicates a slower rate of cognitive gain over the summer months compared with the school-year rate of gain.

Columns IV of Table 2 add Level 2 predictors to the model to test whether the within-person Level 1 intercept estimates, growth-term parameters, and summer adjustment coefficients just reviewed vary significantly in relation to SES, race/ethnicity, and sex. Adding these terms addresses our main substantive concern: The Level 2 effects in column II establish that the SES gap widens over time, but does this happen to the same degree summer and winter?

Several changes are evident comparing Level 2 effects across columns II and IV. The race coefficient in the CAT-V growth term results is non- significant, for example, as is the sex coefficient in the CAT-M results. However, consequences for the family socioeconomic status effect stand out especially: whereas previously the SES effect on growth was large in both domains, in column IV both SES effects are nonsignificant and trivially small. The frame of reference in the two instances is different, though, and this is fundamental to the interpretation: the growth parameters in column II describe the pattern of growth across all periods; in column IV, with the summer adjustment term included in the model, the growth terms pertain to school-year growth specifically. Socioeconomic status thus apparently has no bearing on achievement gains during the school year. Not so for summer gains - the Level 2 SES effect on the summer adjustment coefficient is highly significant in both the CAT-V and the CAT-M results (see column IV). And both coefficients are positively signed, which means that the negative summer adjustment is attenuated for upper SES children relative to lower SES children.

The implications of this adjustment are easiest to see when exact summer gains are calculated, as above. As an example, for children scoring one standard deviation below the samplewide SES mean, the predicted CAT-V change over the first summer is +.55 points; for children at the SES mean, the predicted first-summer gain is +7.32 points; and for children one standard deviation above the SES mean, the predicted gain is +14.09 CAT-V points. ${ }^{18}$

As mentioned, race and gender differences involving school-year growth are also attenuated when the summer adjustment is implemented, although African Americans' school-year gains still lag behind Whites' school-year gains on the CAT$\mathrm{M}$, and there is a borderline significant difference favoring girls on the CAT-V. But the seasonal adjustment has its greatest effect on the size and patterning of SES differences, with achievement disparities larger altogether across socioeconomic lines than across racial/ethnic and gender lines. When the metric coefficients reported in Table 3 are standardized on overall verbal growth to compare effect sizes across Level 2 predictors, the effect coefficients in column II become: SES, .32; race, .23; sex, .17. However, because significant SES differences emerge only during the summer, they must be traced to sources outside school.

Growth models with separate summer adjustments. Table 4 reports results for the growth 
TABLE 4

Growth Curve Analysis With Four Separate Summer Adjustments

\begin{tabular}{|c|c|c|c|c|}
\hline & \multicolumn{2}{|c|}{ CAT-V (Reading) } & \multicolumn{2}{|c|}{ CAT-M (Math) } \\
\hline & Model I & Model II & Model I & Model II \\
\hline Intercept & $283.23(1.54)$ & $282.63(2.55)$ & $293.10(1.20)$ & $297.42(1.92)$ \\
\hline SES & & $16.58(1.75)$ & & $16.86(1.33)$ \\
\hline Race & & $-.82(2.78)$ & & $-4.26(2.12)$ \\
\hline Sex & & $3.77(2.72)$ & & $-1.62(2.08)$ \\
\hline Linear growth term & $57.22(1.51)$ & $56.03(1.96)$ & $49.24(0.96)$ & $49.85(1.31)$ \\
\hline SES & & $-.62(1.06)$ & & $-.51(0.75)$ \\
\hline Race & & $-.87(1.66)$ & & $-2.04(1.18)$ \\
\hline Sex & & $3.16(1.61)$ & & $.97(1.15)$ \\
\hline Quadratic growth term & $-2.01(0.14)$ & $-2.01(0.14)$ & $-1.35(0.09)$ & $-1.35(0.09)$ \\
\hline 1st Summer & $-48.80(2.50)$ & $-47.79(3.99)$ & $-47.70(1.76)$ & $-47.12(2.81)$ \\
\hline SES & & $11.04(2.58)$ & & $4.48(1.82)$ \\
\hline Race & & $-3.32(4.10)$ & & $-.01(2.89)$ \\
\hline Sex & & $2.90(3.99)$ & & $-.33(2.83)$ \\
\hline 2nd Summer & $-47.96(2.10)$ & $-38.89(3.83)$ & $-43.74(1.43)$ & $-43.40(2.63)$ \\
\hline SES & & $5.90(2.62)$ & & $6.94(1.81)$ \\
\hline Race & & $-7.72(4.12)$ & & $1.55(2.85)$ \\
\hline Sex & & $-7.70(4.00)$ & & $-.85(2.79)$ \\
\hline 3rd Summer & $-31.79(2.13)$ & $-33.10(3.95)$ & $-33.55(1.51)$ & $-33.32(2.76)$ \\
\hline SES & & $7.95(2.68)$ & & $3.60(1.86)$ \\
\hline Race & & $2.94(4.21)$ & & $-.42(2.92)$ \\
\hline Sex & & $0.00(4.09)$ & & $.93(2.85)$ \\
\hline 4th Summer & $-20.14(2.52)$ & $-15.66(4.26)$ & $-22.30(1.79)$ & $-25.63(2.97)$ \\
\hline SES & & $5.90(2.74)$ & & 3.04 (1.89) \\
\hline Race & & $-1.19(4.25)$ & & $2.83(2.92)$ \\
\hline Sex & & $-5.98(4.11)$ & & $4.19(2.84)$ \\
\hline
\end{tabular}

Note. Standard errors are shown in parentheses.

Bolded entries are significant at the .05 level. Within-person, Level 1 growth curve estimates are italicized. Coefficients for SES, race, and sex are between-person, Level 2 effects. For CAT-V analysis, $N=448$; for CAT-M, $N=458$.

model specification that implements separate summer adjustments for each summer. Despite the reduced sample size because of missing data when summers are indexed individually, the results that are comparable across Tables 3 and 4 are similar (e.g., school-year CAT gains still do not respond to family SES in either domain).

And what of the more detailed specification of the summer adjustment coefficients? All eight summer adjustment effects are significant (with the estimates for summers 1 and 2 larger than those for summers 3 and 4 in both domains), and for six of the eight, the Level 2 effect of family SES is also significant. These summer adjustments all favor upper SES children. However, the evidence that summer gains are conditional on SES is more compelling for the first two summers than for the last two, at least for quantitative achievement. These results thus give limited support for the idea that the first 2 years of elemen- tary school are distinctive, but strong support for differential summer learning over the primary grades as the scaffolding that supports disparities in school achievement across social lines. Lower SES youth start out behind (i.e., the baseline differences are significant) and during the school year they keep up, but during the summer periods their gains fall short of those registered by upper SES youth. These details of the seasonal patterning of disparities in achievement in reading and math all accord with the descriptive pattern seen earlier, but they are specific to family socioeconomic level: none of the summer adjustment coefficients for sex or race/ethnicity is fully significant under either specification.

\section{Discussion}

The seasonal pattern of learning, documented here in Baltimore, but also at the national level (e.g., Heyns, 1987; Karweit, Ricciuti, \& Thomp- 
son, 1994) and in other localities, including Atlanta (Heyns, 1978), New Haven (Murnane, 1975), and Texas (O'Brien, 1998), undercuts some longstanding but mistaken ideas about schools and social inequality: that schools are ineffectual and unable to equalize educational opportunity, or worse still that they actively handicap disadvantaged children. The "ineffectual" notion traces to a misreading of the Coleman report (Coleman, et al., 1966) that "schools make no difference; families make the difference" (quote attributed to D. P. Moynihan in Hodgson, 1973), and has been reinforced since by overstated claims that school resources have little bearing on achievement outcomes (e.g., see, on the one hand, Hanushek, 1994 and 1997 against, on the other, Finn, 1998; Hedges, Laine, \& Greenwald, 1994; Wenglinsky, 1997), while the "complicity" argument finds support in glaring funding disparities across wealthy and poor communities (e.g., Kozol, 1991).

Families and communities indeed shape children's academic development. Their power is evident in the large learning differences across family SES levels seen in the present results for the summer months; but schooling, too, is a powerful force behind children's academic development. Certainly many disadvantaged children are held back by inequities in the distribution of school resources and associated "opportunities to learn" (e.g., Dougherty, 1996; Murphy \& Hallinger, 1989; Oakes, Gamoran, \& Page, 1992), but this piecemeal approach misses schooling's more generalized, salutary effects. The near parity of school-year learning across social lines establishes that schools play an important compensatory role, carrying along disadvantaged children at a pace close to that of their more advantaged classmates.

Schools do matter, and they matter the most when support for academic learning outside school is weak. School-based public resources do not completely offset the many and varied advantages that accrue to children of privilege by virtue of private family resources outside school (e.g., Coleman, 1990). It is a stretch to think that they would, but this is the implicit standard when test results in Baltimore's schools are found wanting against national norms.

The powerful role of schools in fostering achievement of all children is one lesson informed by a seasonal perspective on learning. A second is that disadvantaged children, on the whole, are capable learners. They keep up during the school year, but before they start first grade and in summers between grades the out-ofschool resources available to them are not sufficient to support their achievement. When our study group started school their pre-reading and pre-math skills reflected their uneven family situations, and these initial differences were magnified across the primary grades because of summer setback despite the equalizing effect of their school experiences.

No doubt, material resources, family processes, and affective context all are implicated in these summer differences (see Entwisle, Alexander, \& Olson, 1997, 2000). If the problem traces to disadvantaged children's out-of-school resource shortfall along these lines, as appears the case, then extending the school's reach through yearround schooling (Gándara \& Fish, 1994), homeschool partnerships that continue when school is closed (Epstein, 1991, 1992), and high-quality summer programs (Cooper, Charlton, Valentine, \& Muhlenbruck, 2000) would seem promising avenues. Indeed, all hold promise, but no single program or intervention is likely to prove sufficient. Accordingly, we conclude by sketching our thoughts on what a more comprehensive agenda might entail.

Prevention, as a rule, is easier than remediation. Accordingly, minimizing the achievement gap at the point of school entry should be the first priority. We know that good preschools can improve disadvantaged children's later school success-not just in test performance, but also in reduction of retention risk, assignment to special education, and even high school dropout (Ramey, Campbell, \& Blair, 1998; Schweinhart \& Weikart, 1998; Temple, Reynolds, \& Ou, 2000). ${ }^{19}$ At present, though, disadvantaged children are the ones least likely to attend preschool (NCES, 1998).

Disadvantaged children also need to attend high-quality, full-day kindergarten programs. Today kindergarten is nearly universal-on the order of $98 \%$ of children attend, ${ }^{20}$ with the majority in full-day programs (59\% in 1998, e.g., U.S. Bureau of the Census, 1999b). And owing to targeted federal and state supplemental funding (e.g., Title I), lower income children, not upper, more often attend full-day programs (e.g., Rothenberg, 1995; U.S. Bureau of the Census, 
1999b). The situation was quite different in the early eighties, though, when the BSS cohort was kindergarten age. Then part-time programs were the norm (U.S. Census, 1999a). ${ }^{21}$ Ten percent of BSS first-graders had no kindergarten and more of those from the poorest families attended halfday programs.

Does this matter? Our evidence certainly suggests that it does. The benefits of full-day as compared to half-day kindergartens for BSS children are considerable. With family background and many other variables allowed for, first graders who attended full-day kindergarten were absent fewer days in first grade, were less often retained, and earned higher marks and test scores in first grade than half-day attendees (Entwisle, Alexander, Cadigan, \& Pallas, 1987; see also Cryan, Sheehan, Weichel, \& BandyHedden, 1992; Karweit, 1989).

Preschool and kindergarten can reduce the achievement gap associated with SES when children start first grade, but to help them keep up later will require extra resources and enrichment experiences, often of the sort that middle class parents routinely provide for their children. This leads us to support summer school or extended year programs just for poor children as well as supplemental school-year services for these children during the early grades.

The Chicago Longitudinal Study shows that intense supplementation of learning resources in the early grades helps poor children maintain the academic edge they get from attending a good preschool and that these benefits then continue into the upper grades (Reynolds, 1994; Reynolds \& Temple, 1998; Temple, Reynolds, \& Miedel, 1998). It is important that, in the Chicago study, neither preschool alone nor school-year supplementation alone proved sufficient. Rather, they are most effective in combination, one building on the other.

The Chicago intervention is not a summer program, but in light of the present results it seems reasonable that summer enrichment programs specifically for disadvantaged students before and after first grade would confer similar, if not greater, benefits. But how should these summer programs be designed? Certainly not like summer programs of the past, which functioned so as to magnify, not shrink, disparities across socio- economic lines (e.g., Cooper, Charlton, Valentine, \& Muhlenbruck, 2000; Entwisle, Alexander, \& Olson, 2000; Heyns, 1978).

A strong curriculum comes first, focused on reading, it being the foundation for all that follows. Heyns (1978) found that the single summer activity most strongly and consistently related to summer learning is reading, whether measured by the number of books read, by the time spent reading, or by the regularity of library usage. Reading during the summer increased the vocabulary test scores of children and had a substantial effect on achievement largely independent of family background. Likewise, BSS children's use of the library in summer, especially taking out books, predicted summer gains in achievement. Educational policies that increase access to books, perhaps through increased library services, stand to have an important impact on achievement, particularly for less advantaged children.

But summer schools should not be limited to traditional academics. Summer programs so far have not addressed the unique contribution that parents and neighborhoods make when school is cut off. We found that better off children in the BSS more often went to city and state parks, fairs, or carnivals and took day or overnight trips. They also took swimming, dance, and music lessons; visited local parks, museums, science centers, and zoos; and more often went to the library in summer. And children who lived in better neighborhoods also played more organized sports in summer. Sports like soccer, field hockey, and softball require children to learn complicated rule systems and take multiple roles. They also can stimulate interest in topics like batting percentages, odds of winning or losing, and the like. ${ }^{22}$ These activities surely are not the only ones that matter, but they all support learning outside the traditional classroom setting, and that gives children an edge.

Building on such leads, probably summer programs for disadvantaged children should supplement academics with a heavy dose of physical activity and enrichment experiences. Such an expanded agenda is important for another reason also: to make summer school fun. Learning works best when children feel they are partners in the enterprise. To realize their potential, summer programs should be engaging and non-punitive. For many disadvantaged, poor-performing children, 
"school" is synonymous with "failure." For them school is not fun, it is punishing. This may be a particular problem in mandatory programs for children who fall short of promotion guidelines (e.g., Bracey, 2000; White \& Johnston, 1999). Putting a positive spin on that will not be easy, but it could well be key.

These suggestions highlight the need to supplement "regular schooling" through a long-term, coordinated program of interventions embodying "best practice" principles. For such interventions to counteract the powerful out-of-school forces that keep too many disadvantaged children from achieving at the level of their potential, they will have to be targeted at low-income children specifically (e.g., universal preschool or summer supplementation for all students would not be consistent with this model; see Entwisle, Alexander, \& Olson, 2000). Such programs will need to begin as early as age 3 and continue thereafter in a sustained way. And even then, "reasonable progress" ought to be the realistic expectation.

We say this because even the best of today's remedies all fall short of achieving "success for all" (e.g., Farkas, Fischer, Dosher, \& Vicknair, 1998; Pinnell, Lyons, DeFord, Bryk, \& Seltzer, 1994; Ross, Smith, Casey, \& Slavin, 1995). There are some children, and in high-poverty settings perhaps many, whose academic problems are not redressed by our current repertoire of well-crafted programs, and to help them probably will require even more far-reaching reforms. Ones that break the stranglehold of the clock and calendar (e.g., Cuban, 1989; Tyack \& Cuban, 1995; Tyack \& Tobin, 1994) may merit special attention. The National Education Commission on Time and Learning (1994, p. 7) puts it this way:

"Decades of school improvement efforts have foundered on a fundamental design flaw, the assumption that learning can be doled out by the clock and defined by the calendar. . . . Some students take three to six times longer than others to learn the same thing. Yet students are caught in a time trap-processed on an assembly line to the minute. Our usage of time virtually assures the failure of many students."

The challenge - a daunting one-is to build more flexibility into the system and to put that added flexibility to good use. But despite poverty and family disruption, it is important to recognize that young children's ability to learn during the school year seems little impaired by scarce family resources. Recognizing the efficacy of elementary schools in leveling the playing field is yet another strategy for closing the achievement gap between rich and poor. Most press coverage of American education today emphasizes the system's failures, especially with respect to the most disadvantaged students. Missed in these reports is the extent to which schools already help make up for deficits in poor children's backgrounds.

Recognition of the power of schools to make a difference in the lives of poor students needs to be coupled with efforts to involve parents and communities in the schooling process so that all parents, not just middle-class parents, are active collaborators in the education of their children. The physical possessions of better off familiescomputers, books and the like-may be of some importance in producing the summer advantage, but probably more important is that parents view themselves as partners in the learning process and possess the psychological resources that support learning. Parents also contribute to the ambience of the neighborhood, if only by selecting themselves into good ones and avoiding bad ones. This lack of resources in family and neighborhood poses a double burden for poor children. Preschool and summer programs, properly organized, can help to potentiate economically disadvantaged parents and their neighborhoods in support of children's academic development.

\section{Notes}

This is a revised version of a paper prepared for "Summer Learning and the Achievement Gap: First National Conference," July 17-18, 2000, Baltimore, $\mathrm{MD}$, an earlier version of which was presented at the 1998 Annual Meeting of the American Association for the Advancement of Science, February 12-17, Philadelphia, PA. We thank Mike Seltzer for help in working through details of the HLM analysis.

${ }^{1}$ See also Phillips, Crouse, and Ralph, 1998.

${ }^{2}$ Likewise, the Black-White gap in achievement increases from the elementary grades through high school (Phillips et al., 1998).

${ }^{3}$ In 1996 (U.S. Department of Education, 1999) almost $10 \%$ of all school-age children attended summer school, including $7.5 \%$ of children in Grades 1-7. According to a recent survey (Borman, 2001), the nation's 100 largest school districts all offer summer 
programs. Ninety-two percent provide remedial instruction during the summer, and $28 \%$ of those entail some form of mandatory attendance (personal communication).

${ }^{4}$ Counting "studies" is complicated in quantitative literature reviews. The two BSS papers covered by Cooper et al. (1996) use the same data source and so constitute one "study" for their purposes, whereas Heyns's two papers use different data sources and so constitute two studies. In fact, the data analyzed in Heyns's 1987 report, the Sustaining Effects Study data, have been analyzed from a seasonal perspective by several researchers (e.g., Carter, 1984; Ginsburg, Baker, Sweet, \& Rosenthal, 1981; Klibanoff \& Haggart, 1981; Bryk \& Raudenbusch, 1988). Cooper et. al.'s (1996) meta-analysis uses 10 effect sizes from one of these reports (Klibanoff \& Haggart, 1981) to reflect the Sustaining Effects Study evidence on the matter.

${ }^{5}$ Karweit, Ricciuti, and Thompson (1994), also analyzing national data (i.e., the Prospects first grade cohort), find much the same during first grade and the summer between first and second grade. However, in second grade, school-year gains favor children in low-poverty schools.

${ }^{6}$ The study by Phillips, Crouse, and Ralph (1998) is broader in scope, covering Black-White differences through Grades 1 to 12 , but it is synthetic, i.e., draws together data from different sources.

${ }^{7}$ For these groups, data coverage is good. In both domains, more than half have complete CAT data, and just under three quarters $(73.5 \%$ on the CAT-V; $73.6 \%$ on the CAT-M) have at least 8 of the 10 scores.

${ }^{8}$ A given achievement gap, say 20 points, will seem more impressive if scores range over a narrow band (e.g., from 0 to 100) than if they range over a broad band (e.g., 0 to 1000). As with testing data generally, CAT variability in the BSS increases with children's age, such that a constant point gap implies a smaller relative difference.

${ }^{9}$ Variations of Table 2 have been reported previously (Alexander \& Entwisle, 1996a, 1996b; Entwisle, Alexander, \& Olson, 1997). This version incorporates recent data enhancements, one being the inclusion of achievement data for some children who transferred to schools outside the BCPS.

${ }^{10}$ Gains per month are only approximate. Testing was done in October and May, but exact dates are not known. The 8-month and 4-month intervals used thus lack precision, but the consequences of this probably are conservative (e.g., some school-year gain is "credited" to the summer, so raw summer gains and gains per month likely err on the high side).
${ }^{11}$ Much the same is observed when the exercise is repeated on a full-panel (i.e., listwise-data-present) basis.

12 The only other strictly comparable analysis of which we are aware is didactic: Bryk and Raudenbush (1988, 1992) model seasonal effects on achievement growth to illustrate within-person applications of HLM. An unpublished paper by Karweit, Ricciuti, and Thompson (1994) reports growth curve results over one summer and two winters using a repeated-measures ANOVA approach that is similar in intent.

13 The specifications for the single summeradjustment model are the same except that only one summer-adjustment parameter is estimated at Level 1. Accordingly, at Level 2, between-person effects are estimated for four rather than seven Level 1 parameters.

${ }^{14}$ In the Level 2 specification, the Level 1 parameters that represent curvature or nonlinearity in the rate of achievement gains (i.e., $\beta_{6 i}$ ) are not allowed to vary in relation to student SES, race, and sex. Preliminary analyses detected no such conditionality involving the deceleration term.

${ }^{15}$ A baseline model that fits just the grand mean is used to partition the variance in test scores into between-person and within-person components. For CAT-V, $25.4 \%$ of the variance is between-person; for CAT-M, $22.6 \%$ of the variance is between-person.

${ }^{16}$ A $1-S D$ difference in family SES corresponds, roughly, to the difference between having high school dropout parents and having parents with some college.

${ }^{17}$ By way of comparison, the actual drop-off observed for the first summer is 1.12 points for the sample as a whole. The estimated effect is much larger, but the estimate derives from an average summer adjustment across all summers and so sacrifices precision.

${ }^{18}$ Recall that the summer adjustment in the model from which these estimates are derived is constrained to be the same all four summers. That constraint is relaxed in Table 4.

${ }^{19}$ For a general overview, see Barnett, 1995.

${ }^{20}$ In 1991, though, $4 \%$ of first and second graders whose parents were high school dropouts had not attended kindergarten versus $1 \%$ or $2 \%$ for all other education categories (U.S. Department of Education, 1992)

${ }^{21}$ And half-day programs remained the majority into the early 1990s (e.g., Love \& Logue, 1992; U.S. Department of Education, 1992).

${ }^{22}$ For a discussion of the link between organized sports and academic progress, see Entwisle, Alexander, and Olson, 1994. 


\section{APPENDIX}

Seasonal Attrition Checks: Background and Other Characteristics from First Grade for Cross-Sectional, Restricted, and Full Panel Samples

\begin{tabular}{|c|c|c|c|}
\hline Sample characteristics & Cross-sectional coverage $^{a}$ & Restricted coverage $^{b}$ & Full panel coverage ${ }^{c}$ \\
\hline Family SES level & $-.04 /(787)$ & $-.05 /(665)$ & $-.13 /(368)$ \\
\hline Pooled $S D$ & {$[.80]$} & & \\
\hline Mother's years of education & $11.67 /(750)$ & $11.72 /(635)$ & $11.60 /(353)$ \\
\hline Pooled $S D$ & [2.55] & & \\
\hline Proportion low income & $.67 /(701)$ & $.67 /(627)$ & $.68 /(366)$ \\
\hline Pooled $S D$ & [.47] & & \\
\hline Proportion two-parent household & $.56 /(754)$ & $.56 /(637)$ & $.54 /(355)$ \\
\hline Pooled $S D$ & {$[.50]$} & & \\
\hline Proportion African American & $.55 /(790)$ & $.57 /(665)$ & $.62 /(368)$ \\
\hline Pooled $S D$ & {$[.50]$} & & \\
\hline Proportion female & $.51 /(790)$ & $.51 /(665)$ & $.53 /(368)$ \\
\hline Pooled $S D$ & {$[.50]$} & & \\
\hline CAT V, fall 1st grade & $280.62 /(691)$ & $280.71 /(665)$ & $280.74 /(368)$ \\
\hline Pooled $S D$ & [40.81] & & \\
\hline CAT M, fall 1st grade & $292.49 /(708)$ & $293.50 /(653)$ & $294.38 /(362)$ \\
\hline Pooled $S D$ & [31.94] & & \\
\hline Academic self-image, spring 1st grade & $4.17 /(717)$ & $4.17(627)$ & $4.20 /(355)$ \\
\hline Pooled $S D$ & [60] & & \\
\hline Marks, fall 1st grade & $2.06 /(704)$ & $2.07 /(623)$ & $2.12 /(354)$ \\
\hline Pooled $S D$ & {$[.71]$} & & \\
\hline Absences, 1st grade & $13.28 /(702)$ & $13.23 /(622)$ & $13.15 /(355)$ \\
\hline Pooled $S D$ & [11.64] & & \\
\hline Work habit ratings, fall 1 st grade & $10.03 /(702)$ & $10.08 /(620)$ & $10.25 /(352)$ \\
\hline Pooled $S D$ & {$[2.12]$} & & \\
\hline
\end{tabular}

Note. Sample sizes are shown in parentheses; standard deviations are shown in brackets.

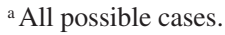

${ }^{\mathrm{b}}$ Sample coverage is cross-sectional but screened on CAT availability for fall of Grade 1 and scores for at least two other time points. Samples are drawn separately for verbal and quantitative domains. Results reported here are for the verbal sample.

${ }^{c}$ The full panel sample screens on complete CAT coverage ( 5 winters and 4 summers), separately by verbal and quantitative domains. Results reported here are for the verbal sample.

\section{References}

Alexander, K. L., \& Entwisle, D. R. (1996a). Early schooling and educational inequality: Socioeconomic disparities in children's learning. In J. Clark (Ed.), Falmer Sociology Series. Hampton, UK: Falmer Press.

Alexander, K. L., \& Entwisle, D. R. (1996b). Schools and children at risk. In A. Booth \& J. Dunn (Eds.), Family-school links: How do they affect educational outcomes? (pp. 67-88). Mahwah, NJ: Lawrence Erlbaum Associates.

Barnett, W. S. (1995). Long-term effects of early childhood care and education on disadvantaged children's cognitive development and school success. The Future of Children, 5(3), 25-50.

Barrett, M. (1990). The case for more school days. The Atlantic Monthly, November. Available online: www.theatlantic.com.
Borman, G. D. (2001). Summers are for learning. Principal, 80(3), 26-29.

Bracey, G. W. (2000, August 8). More school not the answer. USA Today, p. 14A.

Bryk, A. S., \& Raudenbush, S. W. (1988). Toward a more appropriate conceptualization of research on school effects: A three-level hierarchical linear model. American Journal of Education, 97, 65-108.

Bryk, A. S., \& Raudenbush, S. W. (1992). Hierarchical linear models: Applications and data analysis methods. Newbury Park, CA: Sage.

Bryk, A. S., Raudenbush, S. W., \& Congdon Jr., R. T. (1996). HLM: Hierarchical linear and nonlinear modeling with the HLM/2L and HLM/3L programs. Chicago: Scientific Software International.

Carter, L. F. (1984). The sustaining effects study of compensatory and elementary education. Educational Researcher, 13, 4-13. 
Ceci, S. J. (1991). How much does schooling influence general intelligence and its cognitive components? A reassessment of the evidence. Developmental Psychology, 27, 703-722.

Coleman, J. S. (1990). Inequality, sociology, and moral philosophy. In J. S. Coleman (Ed.), Equality and achievement in education (pp. 31-54). Boulder, CO: Westview Press.

Coleman, J. S., Campbell, E. Q., Hobson, C. J., McPartland, J., Mood, A., Weinfeld, F. D., \& York, R. L. (1966). Equality of educational opportunity. Washington, DC: U.S. Government Printing Office.

Cooper, H., Charlton, K., Valentine, J. C., \& Muhlenbruck, L. (2000). Making the most of summer school: A meta-analytic and narrative review. Monograph Series for the Society for Research in Child Development, Ann Arbor, MI.

Cooper, H., Nye, B., Charlton, K., Lindsay, J., \& Greathouse, S. (1996). The effects of summer vacation on achievement test scores: A narrative and meta-analytic review. Review of Educational Research, 66, 227-268.

Cryan, J., Sheehan, R., Weichel, J., \& Bandy-Hedden, I. (1992). Success outcomes of full-day kindergarten: More positive behavior and increased achievement in the years after. Early Childhood Research Quarterly, 7, 187-203.

Cuban, L. (1989). The "at-risk" label and the problem of urban school reform. Phi Delta Kappan, 70, 780-801.

Dougherty, K. J. (1996). Opportunity-to-learn standards: A sociological critique. Sociology of Education, Special Issue, 40-66.

Education Week. (1998, January). Quality counts, '98: An Education Week Pew Charitable Trust report on education in the 50 states. Education Week, 17(17).

Entwisle, D. R., \& Alexander, K. L. (1989). Early schooling as a "critical period" phenomenon. In K. Namboodiri \& R. Corwin (Eds.), Sociology of education and socialization (pp. 27-55). Greenwich, CT: JAI Press.

Entwisle, D. R., \& Alexander, K. L. (1992). Summer setback: Race, poverty, school composition, and mathematics achievement in the first two years of school. American Sociological Review, 57, 72-84.

Entwisle, D. R., \& Alexander, K. L. (1993). Entry into schools: The beginning school transition and educational stratification in the United States. In Annual Review of Sociology (Vol. 19, pp. 401-423). Palo Alto, CA: Annual Reviews.

Entwisle, D. R., \& Alexander, K. L. (1994). Winter setback: School racial composition and learning to read. American Sociological Review, 59, 446-460.

Entwisle, D. R., Alexander, K. L., Cadigan, D., \& Pallas, A. M. (1987). Kindergarten experience:
Cognitive effects or socialization? American Educational Research Journal, 24, 337-364.

Entwisle, D. R., Alexander, K. L., \& Olson, L. S. (1994). The gender gap in math: Its possible origins in neighborhood effects. American Sociological Review, 59, 822-838.

Entwisle, D. R., Alexander, K. L., \& Olson, L. S. (1997). Children, schools, and inequality. Boulder, CO: Westview Press.

Entwisle, D. R., Alexander, K. L., \& Olson, L. S. (2000). Summer learning and home environment. In R. D. Kahlenberg (Ed.), A notion at risk: Preserving public education as an engine for social mobility (pp. 9-30). New York: Century Foundation Press.

Epstein, J. L. (1991). Effects on student achievement of teachers' practices of parent involvement. In S. Silvern (Ed.), Literacy through family, community, and school interaction: Vol 6 (pp. 261-276). Greenwich, CT: JAI Press.

Epstein, J. L. (1992). School and family partnerships. In M. Alkin (Ed.), Encyclopedia of educational research (6th ed., pp. 1139-1151). New York: MacMillan.

Farkas, G., Fischer, J., Dosher, R., \& Vicknair, K. (1998). Can all children learn to read at grade level by the end of third grade? In D. Vannoy \& P. J. Dubeck (Eds.), Challenges for work and family in the twenty-first century (pp. 143-165). New York: Aldine de Gruyter.

Featherman, D. L., \& Stevens, G. (1982). A revised socioeconomic index of occupational status: Application in analysis of sex differences in attainment. In R. M. Hauser, D. Mechanic, A. O. Haller, \& T. Hauser (Eds.), Social structure and behavior: Essays in honor of William Hamilton Sewell (pp. 141-182). New York: Academic Press.

Finn, J. D. (1998). Class size and students at risk: What is known? What is next? Washington, DC: U.S. Department of Education, National Institute on the Education of At-Risk Students.

Gándara, P., \& Fish, J. (1994). Year-round schooling as an avenue to major structural reform. Educational Evaluation and Policy Analysis, 16, 67-85.

Gewertz, C. (2000, June 7). More districts add summer coursework. Education Week. Available online: www.edweek.com.

Ginsburg, A., Baker, K., Sweet, D., \& Rosenthal, A. (1981, April). Summer learning and the effects of schooling: A replication of Heyns. Paper presented at the annual meeting of the American Educational Research Association, Los Angeles, CA.

Hanushek, E. A. (1994). Making schools work. Washington, DC: Brookings.

Hanushek, E. A. (1997). Assessing the effects of school resources on student performance: An up- 
date. Educational Evaluation and Policy Analysis, 19, 141-164.

Hedges, L. V., Laine, R. D., \& Greenwald, R. (1994). Does money matter? A meta-analysis of studies of the effects of differential school inputs on student outcomes. Educational Researcher, 23, 5-14.

Hess, R. D., \& Holloway, S. D. (1984). Family and school as educational institutions. In R. D. Parke (Ed.), Review of child development research. Vol. 7. The family (pp. 179-222). Chicago: University of Chicago Press.

Heyns, B. (1978). Summer learning and the effects of schooling. New York: Academic.

Heyns, B. (1987). Schooling and cognitive development: Is there a season for learning? Child Development, 58, 1151-1160.

Hodgson, G. (1973). Do schools make a difference? The Atlantic, 231, 35-46.

Holmes, E. (1997, 12 November). Pupils lose ground in city schools. The Sun, p. A1.

Karweit, N. (1989). Effective kindergarten practices for students at risk. In R. E. Slavin, N. L. Karweit \& N. A. Madden (Eds.), Effective programs for students at risk (pp. 103-142). Boston: Allyn and Bacon.

Karweit, N., Ricciuti, A., \& Thompson, B. (1994). Summer learning revisited: Achievement profiles of Prospects' first grade cohort. Unpublished manuscript, Abt Associates, Washington, DC.

Kaufman, P., Bradby, D., \& Owings, J. (1992). National Education Longitudinal Study of 1988: Characteristics of at-risk students in NELS:88 (Contractor Report, NCES 1992-042). Washington, DC: U.S. Department of Education, National Center for Education Statistics.

Klibanoff, L. S., \& Haggart, S. A. (1981). Summer growth and the effectiveness of summer school (Report \#8, Technical report to the U.S. Department of Education, Office of Program Evaluation). Mountain View, CA: RMC Research Corporation.

Kozol, J. (1991). Savage inequalities: Children in America's schools. New York: Crown.

Krueger, A. B. (2000, 17 August). Vouchers for summer school could help halt the learning slide. The New York Times, p. C2.

Love, J. M., \& Logue, M. E. (1992). Transitions to kindergarten in American schools: Executive summary (Final report to the Office of Policy and Planning, Contract No. LC88089001). Washington, DC: U.S. Department of Education.

Maryland State Department of Education. (1999a). The fact book, 1998-1999. Baltimore, MD: Author. Maryland State Department of Education. (1999b). Maryland school performance report, 1999: State, systems and schools. Baltimore, MD: Author.
Murnane, R. J. (1975). The impact of school resources on the learning of inner city children. Cambridge, MA: Ballinger.

Murphy, J., \& Hallinger, P. (1989). Equity as access to learning: Curricular and instructional treatment differences. Journal of Curriculum Studies, 21, 129-149.

National Education Commission on Time and Learning. (1994). Prisoners of time. Washington, DC: Author.

Oakes, J., Gamoran, A., \& Page, R. N. (1992). Curriculum differentiation: Opportunities, outcomes and meanings. In P. W. Jackson (Ed.), Handbook of research on curriculum (pp. 570-608). New York: Macmillan.

O'Brien, D. M. (1998). Family and school effects on the cognitive growth of minority and disadvantaged elementary students. Paper presented at the annual meeting of the Association for Public Policy Analysis and Management, October 29-31.

Phillips, M., Crouse, J., \& Ralph, J. (1998). Does the black-white test score gap widen after children enter school? In C. Jencks \& M. Phillips (Eds.), The black-white test score gap (pp. 229-272). Washington, DC: Brookings.

Pinnell, G. S., Lyons, C. A., DeFord, D. E., Bryk, A. S., \& Seltzer, M. (1994). Comparing instructional models for the literacy education of high-risk first graders. Reading Research Quarterly, 29(1), 9-39.

Ramey, C. T., Campbell, F. A., \& Blair, C. (1998). Enhancing the life course for high-risk children: Results from the Abecedarian Project. In J. Crane (Ed.), Social programs that work (pp. 163-183). New York: Russell Sage Foundation.

Reynolds, A. J. (1994). Effects of a preschool plus follow-on intervention for children at risk. Developmental Psychology, 30, 787-804.

Reynolds, A. J., \& Temple, J. A. (1998). Extended early childhood intervention and school achievement: Age thirteen findings from the Chicago Longitudinal Study. Child Development, 69, 231-246.

Ross, S. M., Smith, L. J., Casey, J., \& Slavin, R. E. (1995). Increasing the academic success of disadvantaged children: An examination of alternative early intervention programs. American Educational Research Journal, 32, 773-800.

Rothenberg, D. (1995, May). Full-day kindergarten programs. ERIC Digest. ERIC Digests, ED382410. Available online: www.ed.gov/databases/ERIC_ Digests.

Schneider, B. L. (1980). Production analysis of gains in achievement. Paper presented at the annual meeting of The American Educational Research Association, Boston, MA. 
Schweinhart, L. J., \& Weikart, D. P. (1998). High/ Scope Perry Preschool Program effects at age twenty-seven. In J. Crane (Ed.), Social programs that work (pp. 148-183). New York: Russell Sage.

Scott-Jones, D. (1984). Family influences on cognitive development and school achievement. In E. W. Gordon (Ed.), Review of Research in Education (Vol. 11, pp. 259-304). Washington, DC: American Educational Research Association.

Slaughter, D. T., \& Epps, E. G. (1987). The home environment and academic achievement of black American children and youth: An overview. Journal of Negro Education, 56, 3-20.

Stephens, J. M. (1956). Educational psychology. New York: Holt, Rinehart \& Winston.

Temple, J. A., Reynolds, A. J., \& Miedel, W. T. (1998). Can early intervention prevent high school dropout? Evidence from the Chicago Child-Parent Centers (Institute for Research on Poverty Discussion Paper No. 1180-98). Madison: University of Wisconsin.

Temple, J., Reynolds, A. J., \& Ou, S. R. (2000, 18-19 October). Grade retention and school dropout: Another look at the evidence. Paper presented at the National Invitational Conference, Can Unlike Students Learn Together? Grade Retention, Tracking, and Grouping. Alexandria, VA. (Sponsored by the Temple University Center for Research in Human Development and Education Laboratory for Student Success).

The Sun. (1999). The ultimate quide to Baltimore schools. Baltimore, MD: Author.

Tyack, D., \& Cuban, L. (1995). Tinkering toward Utopia: A century of public school reform. Cambridge, MA: Harvard University Press.

Tyack, D., \& Tobin, W. (1994, Fall). The grammar of schooling: Why has it been so hard to change? American Educational Research Journal, 31, 453-479.

U.S. Bureau of the Census. (1999a). School enrollment-social and economic characteristics of students: October 1997. (Current Population Reports P20-516). Washington, DC: Author.

U.S. Bureau of the Census. (1999b). School enrollment-social and economic characteristics of students (update): October 1998, Table 4. (Current Population Reports P20-521). Washington, DC: Author.

U.S. Department of Education, National Center for Education Statistics. (1992). Experiences in child care and early childhood programs of first and second graders (NCES 1992-005, by J. West, E. G. Hausken, K. Chandler, \& M. Collins). Washington, DC: Author.

U.S. Department of Education, National Center for Education Statistics. (1998). The condition of edu- cation 1998 (NCES 1998-013). Washington, DC: Author.

U.S. Department of Education, National Center for Education Statistics. (1999). Digest of education statistics, 1998 (NCES 1999-036 by T. D. Snyder, C. M. Hoffman, \& C. M. Geddes). Washington, DC: Author.

U.S. Department of Education, National Center for Education Statistics. (2000). America's kindergarteners: Findings from the Early Childhood Longitudinal Study, kindergarten class of 1998-99, Fall 1998 (NCES 2000-070 by J. West, K. Denton, \& E. Germino-Hausken). Washington, DC: Author.

Wenglinsky, H. (1997). When money matters. Princeton, NJ: Educational Testing Service, Policy Information Center.

White, K. (1999, October 27). Quietly, the school calendar evolves. Education Week. Available online: www.edweek.org.

White, K. A., \& Johnston, R. C. (1999, September 22). Summer school: Amid successes, concerns persist. Education Week on the Web, 19(3). Available online: www.edweek.org.

White, W. (1906). Reviews before and after vacation. American Education, 10, 185-188.

\section{Authors}

KARL L. ALEXANDER is the John Dewey Professor of Sociology at The Johns Hopkins University, 3400 N. Charles Street, Baltimore, MD 21218; e-mail: karl@jhu.edu. His interests center on problems of educational stratification that can be addressed via organizational, social-psychological, and life course perspectives. The Beginning School Study (BSS) has been his primary research activity since the project commenced in 1982. With Doris Entwisle and Susan Dauber, he is revising and updating a monograph on grade retention, On the Success of Failure: A Reassessment of the Effects of Retention in the Primary Grades (Cambridge University Press, 1994). He also is working on several projects that examine the early adult transition through the lens of the BSS; one project focuses on mode of high school exit.

DORIS R. ENTWISLE is professor emerita of sociology at The Johns Hopkins University. She has been interested for many years in the effects of social structure on human development in middle childhood and adolescence. Her current research concerns how youth in the Beginning School Study manage to juggle their work and school roles as they make the transition to adulthood. She recently published a book (with Karl L. Alexander and Linda S. Olson) titled Children, Schools, and Inequality (Westview-Perseus, 1997), which discusses the ways in which social and 
financial disadvantage alters the life paths that children take through elementary school. A former Guggenheim Fellow, in 1997 she received the Society of Research in Child Development Award for Distinguished Scientific Contributions to Child Development.

LINDA STEFFEL OLSON is a senior research assistant in the Department of Sociology at The Johns Hopkins University. She has been associated with the
Beginning School Study for the past 15 years. Her interests center on the effects of social structure on schooling outcomes.

Manuscript received September 27, 1999 Revision received November 3, 2000 Accepted February 7, 2001 